Published in final edited form as:

Vasc Med. 2011 August ; 16(4): 288-301. doi:10.1177/1358863X11398519.

\title{
Acrocyanosis: The Flying Dutchman
}

\author{
Andrew K Kurklinsky ${ }^{1}$, Virginia M Miller ${ }^{2}$, and Thom W Rooke ${ }^{1}$ \\ ${ }^{1}$ Gonda Vascular Center, Mayo Clinic, Rochester, MN, USA \\ ${ }^{2}$ Departments of Surgery, Physiology and Biomedical Engineering, Mayo Clinic, Rochester, MN, \\ USA
}

\begin{abstract}
Acrocyanosis is symmetric, painless, discoloration of different shades of blue in the distal parts of the body that is marked by symmetry, relative persistence of the skin color changes with aggravation by cold exposure, and frequent association with local hyperhidrosis of hands and feet. Described over a century ago and despite seeming familiarity, it remains a poorly understood condition that shares much in clinical presentation with other conditions characterized by skin color changes in the distal parts of the body. The diagnosis remains mostly clinical, and pathological mechanisms vary suggesting that acrocyanosis may not be a single entity. We performed an extensive literature review to summarize existing knowledge about the demographics, pathology, diagnosis, and treatment of this condition.
\end{abstract}

\section{Keywords}

acrocyanosis; arterial occlusive disease; arteries; blood flow velocity; capillaries; chilblains; cyanosis; ischemia; vascular diseases; vasospasm

\section{Introduction}

The term 'acrocyanosis' has been in use for over a century, yet the phenomenon remains poorly understood. In many ways it is a Flying Dutchman: every physician has heard about it, many have seen it, yet no one knows for sure what it is. This review summarizes existing knowledge regarding the demographics, pathology, diagnosis, and treatment of the condition.

\section{Methods}

The literature search combined using controlled vocabulary and text words in the following databases: (1) OVID MEDLINE 1947 - present, text word "Acrocyano* OR (cyanosis AND (explode toes/OR explode fingers))"; (2) EMBASE 1988 - present, subject heading OR text word "Acrocyanosis/OR acrocyano*"; (3) Index Catalog of the Surgeon General 18781937, text word; and (4) SCOPUS "acrocyan*”, text word and selected bibliography from

(C) The Author(s) 2011

Corresponding author: Andrew K Kurklinsky, Vascular Medicine Fellow, Gonda Vascular Center, Mayo Clinic, Rochester, MN 99505, USA, kurklinsky.andrew@mayo.edu.

Financial support and disclosures

Thom W Rooke and Virginia M Miller: none. Andrew K Kurklinsky is a vascular medicine fellow at Mayo Clinic, Rochester, MN, supported by NIH Grant Number K12HL083797.

The contents of this publication are solely the responsibility of the authors and do not necessarily represent the official views of the NIH. 
published articles. Articles in English were reviewed and then supplemented by references from within these articles. This review is limited by the exclusion of a large body of literature in other languages, mostly French, German and Italian.

\section{Definition}

Despite seeming familiarity, the term 'acrocyanosis' is commonly misused ${ }^{1-3}$ or is used liberally to describe other conditions that are characterized by peripheral cyanosis. Many reports lack sufficient details to judge whether the term is applied correctly. Some use the term 'intermittent acrocyanosis' or describe 'peripheral acrocyanosis'. This is particularly true of many reports of putative secondary acrocyanosis. The degree of confusion surrounding this phenomenon is well illustrated by a study of physicians with similar experience in the treatment of eating disorders that revealed poor interobserver correlation of detection of acrocyanosis (one of the most common physical findings ${ }^{4}$ ) in these patients. ${ }^{5}$

Thus, while the best definitions of acrocyanosis focus on clinical description, there is no uniform definition of acrocyanosis. In this review, much in line with the original definition by Crocq, ${ }^{6}$ acrocyanosis is defined as a painless condition characterized by discoloration of different shades of blue in the distal parts of the body (most commonly in the hands, feet, and face) that is marked by symmetry and persistence of color changes aggravated by cold exposure, and which is frequently associated with local hyperhidrosis of hands and feet. Additional characteristics that help differentiate acrocyanosis from other conditions with similar features are described below. However, any attempt to rely on a purely clinical definition is, in a sense, a compromise that may lump conditions with similar clinical manifestations, yet very different pathologic mechanisms, into the same group. Indeed, even 80 years ago, acrocyanosis was described as a syndrome of variable etiology with suspected 'fundamentally different causes'. 7

Based on similarity of clinical manifestations, acrocyanosis is commonly listed in the group of conditions known as acrosyndromes. These acrosyndromes may overlap, making clinical discernment challenging. Acrocyanosis should be distinguished from Raynaud's phenomenon, pernio, acrorygosis, erythromelalgia, and other members of this family. ${ }^{8-11}$ The differences among various acrosyndromes are made largely on clinical grounds; in many cases there are significant commonalities of pathological mechanisms. Indeed, some authors describe acrocyanosis as a variant of Raynaud's phenomenon. ${ }^{12}$

When no apparent cause can be determined, acrocyanosis is considered primary (idiopathic, essential) and is believed to be a benign condition that typically requires no specific treatment, does not evolve into connective tissue disease or other serious diseases, and may spontaneously resolve. As originally proposed by Hallam, ${ }^{7}$ it might be a single entity or a number of different entities with very similar clinical manifestations but different pathological mechanisms. Secondary acrocyanosis is a manifestation of other diseases (see summary in Table 1). As such, it often correlates with their severity, may portend a worse prognosis, and in some cases may be the first manifestation of these conditions.

\section{Demographics}

In the English literature, demographics of primary acrocyanosis have not been a focus of a dedicated study. Influence of such factors as sex, age, presence of skin pigment, geographical locale (latitude; urban versus rural setting), or influence of hormonal status remain uncertain. In one study involving residents of a psychiatric institution, acrocyanosis was present in 50 of 110 people, but there was clearly a selection bias and the symptoms of acrocyanosis were not present in many patients under normal conditions. ${ }^{91}$ Merlen reports an acrocyanosis prevalence of $12-13 \%$ referring to a personal survey of the 3000-person 
'homogenous urban population' of Lille, but offers no assessment method details. It is unknown what other factors could be present in that population to affect prevalence, but it is possible that it was lower than elsewhere given a relatively warm climate. ${ }^{8}$ Environmental factors may greatly influence prevalence estimates but are not always known or easily assessed. For example, chronic arsenic toxicity, commonly accompanied by acrocyanosis, is endemic in some areas and is known as 'black foot disease'. ${ }^{92,93}$ In a single city in Chile with well-documented increased arsenic exposure in the community, acrocyanosis was present in $36.8 \%$ of people. ${ }^{57}$

Primary acrocyanosis is mostly a disease of young adults. It is commonly diagnosed in adolescence, with most cases in the second and third decades of life. Few cases persist into middle age and almost none are seen after menopause, suggesting hormonal influences on the underlying mechanisms. ${ }^{1,7}$ In pediatric practice, acrocyanosis is less common. It is more frequently a benign phenomenon, ${ }^{19}$ although it is not clear if the same mechanisms are responsible in children as in adults. However, cases of secondary acrocyanosis may be associated with serious disorders such as mitochondrial diseases. ${ }^{59,64,65,94}$ Acrocyanosis may have familial presentation. ${ }^{1,95}$ Sex predilection is uncertain, although in most reports the majority of patients are women. ${ }^{1,10,91,96,97}$ The reported female:male ratio of $6-8: 1^{1,98}$ may result from selection bias.

Prevalence of secondary acrocyanosis is known better in some cases thanks to studies of the primary condition. Thus, in association with involuntary starvation, frequency varies from $10 \%$ to $75 \% 26,27$ and in anorexia nervosa from $21 \%$ to $40 \%$ on physical exam (up to $81 \%$ in questionnaires). ${ }^{4,99,100} \mathrm{Up}$ to $24 \%$ of all patients with cancers may present with acrocyanosis. ${ }^{101}$

\section{Pathology \\ Histopathology}

Histopathological studies do not offer much clarity into the nature of acrocyanosis as observed tissue changes are not remarkable, consistent, or specific. The medial coats of arterioles are within the upper limits of normal. Local edema and fibrosis with dilated superficial capillaries and sometimes new vessel formation may be observed. ${ }^{91}$ Non-specific mild perivascular lymphocytic infiltrates may be seen. ${ }^{102}$ The increased number and size of arteriovenous anastomoses are common. ${ }^{8,103}$ Abnormally twisted collagen fibrils arranged in characteristic patterns can be observed by electron microscopy in normal-appearing skin biopsied from elbows in many patients with essential acrocyanosis. Similar changes may be seen in normal-appearing skin of patients with Ehlers-Danlos syndrome (EDS), while many EDS cases are accompanied by acrocyanosis. It has been suggested that acrocyanosis is a hereditary vascular dysfunction of the pericytes in the subpapillary vascular plexus. ${ }^{75,76} \mathrm{In}$ acrocyanosis accompanying anorexia nervosa, histology of skin biopsies shows marked telangiectasia and a mild perivascular inflammatory cell infiltrate within the papillary and superficial reticular dermis. ${ }^{25}$

\section{Pathophysiology}

Although clinically similar to Raynaud's phenomenon in several ways, primary acrocyanosis has received much less attention and remains less researched, with most pathophysiologic studies performed decades ago. Early experimental evidence suggested that in many cases primary acrocyanosis is a vasospastic disorder. Capillary pressure was thought to be high due to constriction of the venules without alteration of the venous pressure. ${ }^{104}$ Subsequently, it was determined that capillary pressures in acrocyanosis are low. Capillary flow is sluggish and has poor pressure variability; both are reversible with rewarming. Constriction has been thought to occur within capillaries as constriction of the 
venules would result in capillary engorgement. ${ }^{105}$ These findings were confirmed by Bollinger et al. who also reported some cases of flow reversal at low skin temperatures. These flow pattern abnormalities, suggesting incoherent actions of precapillary vessels, distinguished acrocyanosis from primary Raynaud's disease. ${ }^{106-108}$ Whether patients with acrocyanosis exhibit vasodilation with prolonged cold exposure and whether its pattern is similar to that in normal individuals or those with Raynaud's phenomenon is unknown. ${ }^{109}$

Since rewarming of only a part of the hand produces a sharp demarcation line between the cyanotic and warm zones, the primary vessel defect is localized to small but not larger arteries in acrocyanosis. $7,95,110,111$ This conclusion is also supported by the clinical observation that the demarcation line of the cyanosis is not above the wrist/ankle level but is more commonly confined to distal portions of fingers and toes. Blockade of the autonomic ganglia, ${ }^{112}$ local application of histamine, or blocking of the ulnar nerve ${ }^{110}$ resulted in rise of the skin temperatures in acrocyanosis. However, color restoration is markedly delayed in blanched skin and the skin color does not normalize even in the presence of the nerve block until local temperature is increased. ${ }^{111}$ Exaggerated sympathetic reflex activity is not sufficient to explain acrocyanosis and thus other factors have been suspected. ${ }^{96,110,111}$ Potential mediators of altered vasoconstriction in acrocyanosis include adrenaline, noradrenaline, and/or serotonin, which are increased in a third of the cases. ${ }^{1}$ The endothelium-derived vasoconstrictor endothelin- 1 is also elevated in patients with primary acrocyanosis at resting conditions and with exposure to cold. ${ }^{113}$

Small vessels are involved and arteriovenous subpapillary plexus shunting occurs in acrocyanosis. Whether the 'vascular fault' responsible for acrocyanosis is localized to predominantly the venous or arterial portion of the circulation is a subject of debate. Sagher et al. suggest that a lack of venous tone prevails as edema of the fingers and limbs is often present in association with striking dilatation of capillaries and venules. In one-third of patients, the subpapillary vessels are also dilated, while in some it is the only finding, suggesting that more than one mechanism may produce the skin changes. ${ }^{7114}$ Cyanosis disappears with elevation of the hands above the head, arguing against venous obstruction $^{110}$ and supporting possible sub-capillary venous plexus dilatation. Restoration of hand temperature following cold exposure is quicker with hands at the heart level than in the dependent position (Heidelmann's test). ${ }^{95}$ On serial arteriophlebography, venous return time is markedly shortened in patients with acrocyanosis compared to healthy individuals. ${ }^{98} \mathrm{It}$ was also proposed that shunting through the arteriovenous anastomoses aggravates deceleration of capillary flow leading to hypoxia. ${ }^{103}$ However, shunts are not seen in all patients and in some cases blood transit through the hand is clearly slowed. In comparison to healthy individuals, in acrocyanosis patients, following local application of heat, there is both an impaired rise in oxygen and delayed fall in carbon dioxide partial pressures in the venous blood (i.e. impaired 'arterialization' of venous blood). Although less prominent in acrocyanosis than in Raynaud's disease, these factors nonetheless reflect an impaired ability of vessels to dilate, with decreased transit of blood through the tissue. ${ }^{115}$

In addition to dysfunction of the small vessels, rheologic and fibrinolytic properties of the blood may be altered in acrocyanosis, $7,10,98,116$ although this claim has been disputed. ${ }^{108,117}$

\section{Pathophysiology of secondary acrocyanosis}

Specific causes of secondary acrocyanosis vary. Rarely, hypersensitivity reactions may contribute to dilatation of the venous bed. ${ }^{83,118,119}$ On the other hand, antagonism of $\mathrm{H}_{1}$ and $\mathrm{H}_{2}$-h istaminergic receptors as well as an increase in plasma norepinephrine and activation of $\alpha-1$ adrenergic receptors are the supposed mechanisms of acrocyanosis induced by tricyclic antidepressants. ${ }^{41,42}$ Methemoglobinemia and sulfhemoglobinemia may produce acrocyanosis with characteristically very dark blood and hypoxemia. ${ }^{3,51}$ Chronic arsenic 
poisoning may produce acrocyanosis through inhibition of prostacyclin synthase, which appears lacking or undetected in the endothelium of these patients. As a result, formation of intravascular clots and inflammation of the vascular wall occur, which lead to gangrene and amputations of the limbs in the majority of the cases..$^{92}$ Damage to endothelial cells, increased coagulability with circulating platelet aggregates, induced oxidative stress, and smooth muscle cell proliferation are other described pathological mechanisms in black foot disease. ${ }^{120,121}$ In cases of paraneoplastic acrocyanosis, small vessel thrombosis due to increased blood viscosity and proliferation of cellular elements may be responsible for the skin changes. ${ }^{122}$ In the setting of severe systemic illness requiring treatment with vasopressors, it may be difficult to single out the primary mechanism underlying acrocyanosis, particularly when disseminated intravascular coagulation (DIC) complicates the clinical picture. In these instances, acrocyanosis may occur even at relatively low doses of the pressor drug infusion. ${ }^{47,123}$ In anorexia nervosa, acrocyanosis is thought to be due to persistent venoconstriction associated with impairment of thermoregulation with reduced and delayed responsiveness to both vasodilator and vasoconstrictor agents. ${ }^{124}$

\section{Parallels between mechanisms of acrocyanosis and Raynaud's phenomenon}

In a detailed review of mechanisms of Raynaud's phenomenon, Cooke and Marshall ${ }^{12}$ include acrocyanosis as a Raynaud's phenomenon variant. However, the clinical differences are appreciable and while it appears that the two entities have some common pathologic mechanisms, it is less clear what mechanisms set them apart. Treatment by sympathectomy was not sufficient for complete cure in either of these conditions. It is possible that distribution of adrenoreceptors, alpha-2 type in particular, contributes to acrocyanosis. To our knowledge, with the exception of a single trial of indoramin, a selective alpha-1 antagonist, no experiments similar to those performed in Raynaud's phenomenon have been done in acrocyanosis. Indoramin significantly increased blood flow in the affected fingers of acrocyanosis patients, although no clinical correlations were made. ${ }^{12,125}$ Whether central neural abnormalities with impaired impulse habituation observed in Raynaud's phenomenon ${ }^{12}$ hold true in acrocyanosis is also unknown, although acrocyanosis may occur in apprehension of cold exposure. ${ }^{111}$ Similarly to Raynaud's phenomenon, the role of serotonin and endothelin-1 in the vasospasm of acrocyanosis is not clear. ${ }^{1,12,113}$ There is a report of serotonin reuptake inhibitors (SSRI) unmasking carcinoid syndrome with resultant acrocyanosis. ${ }^{116,126}$ Whether oxidative stress, cyclo-oxygenase (COX), and estrogen may have negative effects on vascular signaling, atherosclerosis and restenosis, ischemiareperfusion damage, acetylcholine-induced vasodilation, and digital flow in premenopausal women with acrocyanosis similar to those in patients with Raynaud's phenomenon is unknown. ${ }^{12}$

\section{Diagnosis \\ Clinical features}

Clinical observations remain key to the diagnosis of acrocyanosis. ${ }^{1,91,104}$ Bluish discoloration of the skin may have different hues, affecting fingers and toes and involving, in some cases, the entire hands and feet and even forearms (Figure 1). Parts of the head, especially the nose tip and ears, may be affected although it is seen less frequently. Most often, acrocyanosis is confused with Raynaud's phenomenon as both are aggravated by cold and emotional stress; both present with blue discoloration of the fingers and hyperhidrosis. Acrocyanosis is differentiated from Raynaud's phenomenon by relative persistence of skin color changes, symmetry, and absence of paroxysmal pallor. However, Raynaud's attacks superimposed on acrocyanosis are not uncommon and may complicate the diagnosis. While Raynaud's phenomenon is marked by clear paroxysms, the persistence of color changes in acrocyanosis is also relative as many cases will improve in the summer both clinically and 
on capillaroscopy. Almost all acrocyanosis patients have marked clamminess and hyperhidrosis of hands and feet, which may be very striking on the volar surfaces and tend to worsen in warmer temperatures while the color changes improve. Finger color normalizes when hands are transferred from the dependent to horizontal position. ${ }^{110}$ Pain or significant discomfort is uncommon in acrocyanosis.

Crocq's sign described in the earliest report of acrocyanosis ${ }^{6}$ is the slow and irregular return of the blood from the periphery (but not from beneath) to the center in the area of blanching produced by pressure on the skin. It is characteristic of, but not specific for, acrocyanosis. $1,7,91,104$

Although primary acrocyanosis is generally considered a benign condition implying no evolution to more serious problems, few studies report long-term follow-ups. ${ }^{103,127}$ Presence of pain, ulcerations and gangrene should lead to an alternative diagnosis. ${ }^{1}$ Associations of primary acrocyanosis with other conditions (e.g. rheumatic fever, migraine, vasomotor rhinitis, and even brief recurrent hemiparesis) have been reported. ${ }^{1,81,111}$ Age may be helpful in diagnosis as primary acrocyanosis often resolves in middle age. ${ }^{7}$

Secondary acrocyanosis is often marked by asymmetry, associated pain and tissue damage, increased variability of manifestations, or the presence of various signs of the primary disorder which may become fully manifest with the passage of time.

Peripheral cyanosis resulting from hypoxemia can be distinguished from acrocyanosis by abnormalities of the cardiopulmonary system and cyanosis of the mucosae. Analysis of arterial blood gases confirms hypoxemia.

Acrocyanosis may coexist with and is more common in patients with erythema pernio (chilblains), which is characterized by rapid onset, itching, pain, tenderness, and quick improvement with warming of the weather. ${ }^{7,91}$ Acrocyanosis is also a common finding between episodes of erythromelalgia. ${ }^{128}$

\section{Laboratory and instrumental methods}

There is a paucity of objective methods to aid clinical diagnosis, and the absence of an animal model limits research options. In primary acrocyanosis, there are no specific laboratory abnormalities. Protein $\mathrm{C}$ and $\mathrm{S}$ deficiencies apparently do not confer an increased risk of acrosyndromes. ${ }^{129}$ In patients with anorexia, differences in leukocyte and eosinophil counts were predictive of acrocyanotic manifestations. It was suggested that microvascular leukocyte activation and recruitment may be responsible, ${ }^{130}$ although others found no correlation with any laboratory values. ${ }^{131}$

Oscillometry over the radial artery and Doppler ultrasound of the digital vessels are often reduced in acrocyanosis. Plethysmography showed hyposphygmia, delay of the anacrotic wave and peak time, and accentuated dicrotism. ${ }^{1,2}$ Transcutaneous oximetry showed decreased oxygen tensions. ${ }^{10}$ Skin temperatures and blood flows (measured by plethysmography) were significantly lower in patients with acrocyanosis than in healthy referents. ${ }^{132}$ Skin temperatures at the tips of fingers and toes are very sensitive to ambient temperature and are markedly reduced in comparison to temperatures over the wrist and ankle. This temperature differential correlates positively with the disease severity. Temperature-related findings improve in the summer. ${ }^{1,2,91,95,110}$

\section{Capillaroscopy}

Capillaroscopy to assess capillary morphology, distribution, and blood flow is the most extensively studied diagnostic technique for acrocyanosis. It may help distinguish primary 
acrocyanosis from connective tissue disorders (CTD) in early stages when other clinical symptoms of CTD are not yet manifest. Capillaroscopy can be performed at the nail fold, conjunctiva, lip, or tongue. ${ }^{133}$ In one-fourth of patients with acrocyanosis, characteristic changes may not be seen in the nail fold, although they are seen in the conjunctival capillaries. ${ }^{114}$ The appearance of normal capillaries at the base of the fingernail is marked by great variability in structure and there is more than one normal flow pattern. ${ }^{105,106}$ The normal 7-8 $\mu \mathrm{m}$ capillary diameter increases in acrocyanosis to $15-40 \mu \mathrm{m}$ with marked congestion and dilatation of the terminal loop. Arterial and venous limbs of the capillary are also dilated with the arteriolar limb approximating the venous limb in diameter. ${ }^{114}$ Such capillaries are known as 'megacapillaries'; however, different authors use different dimensions, describe a variety of megacapillaries, and debate whether the striking dilatation of the efferent loop is a reliable finding. ${ }^{108,111,127,134-136}$ There is a high risk of falsepositive detection of megacapillaries in patients with acrocyanosis, especially in combination with Raynaud's phenomenon. ${ }^{136}$ Despite these difficulties, detection of megacapillaries may be helpful as they are not normally seen in systemic lupus erythematosus or rheumatoid arthritis. They are also uncommon in polymyositis, but are common in scleroderma and mixed connective tissue disease. ${ }^{134}$

There is lack of agreement on capillaroscopic criteria of acrocyanosis and CTDs. ${ }^{1,9,10,81,114,127,135,136}$ The capillaroscopic pattern of acrocyanosis is marked by hemorrhages, pericapillary edema, and widened capillaries. However, these findings are not unique to acrocyanosis and differentiation from other conditions may be challenging. ${ }^{136}$ Capillary density in acrocyanosis is reduced compared to healthy controls, but is significantly greater than that of patients with systemic sclerosis. ${ }^{136,137}$ Tortuous capillaries are non-specific and may be seen in individuals without acrocyanosis.

Even with capillaroscopy, it is not always clear whether the cases of acrocyanosis in a particular study are primary or secondary, and whether absence of an apparent association between acrocyanosis and another condition holds true over time. In one study, at the end of a 6-year follow-up of semi-quantitative nail fold capillary findings, most of the patients with few enlarged capillaries and no capillary rarefaction in the beginning of the study were diagnosed with primary acrocyanosis and none progressed to scleroderma. ${ }^{127}$ In a study of HIV-infected patients with acrocyanosis and Raynaud's -nomenon, capillaroscopy failed to demonstrate differences from healthy volunteers, except in advanced stages of HIV. ${ }^{84}$ Acrocyanosis is common in anticardiolipin-positive patients. However, nail fold capillary microscopy failed to distinguish them from anticardiolipin-negative matched controls in a case-control study. ${ }^{138}$ Seasonal variations of the capillary enlargement have been observed; capillary changes may also diminish after menopause.

Good inter- and intraobserver agreements have been shown with regards to only some capillaroscopic measures. Ultimately, capillary density is the most reliable capillaroscopic parameter in differentiating acrocyanosis from CTD ${ }^{135}$ In many circumstances, simple qualitative analysis is not reliable and the need for greater diagnostic precision has prompted development of more sophisticated semi-quantitative and quantitative capillaroscopic methods and fluorescent capillaroscopic videomicroscopy. ${ }^{9,107,139-141}$

In summary, capillaroscopy has been used as a research tool for almost a century but has not become the gold standard for the clinical diagnosis of acrocyanosis. It is difficult to distinguish among different acrosyndromes based only on changes of capillary flow as these parameters are sensitive but not highly specific. Abnormal capillaroscopy may be seen without full disease symptoms, while classical clinical findings may be present with normal capillaroscopy. It may be helpful as a diagnostic tool in some borderline cases. ${ }^{2}$ Even with 
the use of capillaroscopy, the morphologic findings are not conclusive and acrocyanosis remains 'a functional disease with organic-like morphological abnormalities'. 9,141

\section{Secondary acrocyanosis}

Numerous associations of pathological conditions with acrocyanosis have been described (see summary in Table 1). Incomplete work-up for possible secondary causes of acrocyanosis may result in an erroneous diagnosis. ${ }^{3,142}$ The secondary nature of acrocyanosis is evidenced by its resolution with treatment of the primary condition, disappearance of the putative causative factor (e.g. cryoglobulins), or withdrawal of an offensive agent. In many of these cases the responsible pathological mechanisms produced by the primary condition have been identified. Onset may be rather rapid with a clear recollection of the time and circumstances of the first episode by the patient. Tissue damage, including ulcerations and gangrene, may reflect the severity of the underlying primary condition and pain may be present.

Secondary acrocyanosis often affects digits asymmetrically and may be associated with pain and tissue loss. With the exception of perhaps only some cases of secondary acrocyanosis, it is not justifiable to suggest that acrocyanosis should be known as 'blue toe syndrome'. ${ }^{143}$ Acrocyanosis is often described in the context of blue toe syndrome, resulting, in classical descriptions, from atheromatous embolization of the terminal vessels ${ }^{144}$ in the setting of oral anticoagulant therapy ${ }^{21,145}$ but also from plaque disruption during vessel catheterization. ${ }^{20,146,147}$ Since the term 'blue toe syndrome' was introduced, its list of etiologies has expanded so that there is a significant overlap with the differential list of secondary acrocyanosis (Table 1). ${ }^{148}$ In fact, in some instances, the distinction between blue toe syndrome and secondary acrocyanosis may be artificial and confusing. It may be difficult to decide which of the two terms is more appropriate. A practical diagnostic algorithm of a 'purple digit' was offered by Brown et al. ${ }^{149}$ and may be well applied to differentiate secondary acrocyanosis from similar conditions (Figures 2 and 3).

In addition to SSRIs, tricyclic antidepressants, and norepinephrine mentioned previously, other medications have been associated with acrocyanosis. With vasopressors, acrocyanosis is apparently dose-related but is not necessarily associated with other vascular complications such as intestinal ischemia. ${ }^{46}$ However, in some cases complications such as digital necrosis may occur. ${ }^{150}$ It is hard to tell if different outcomes are agent-specific or result from other factors that impact severity, such as the presence of DIC. ${ }^{47,151,152}$ Up to $6 \%$ of renal transplant patients treated with sirolimus may develop acrocyanosis. ${ }^{48}$ In rare cases, acrocyanosis has been associated with treatment with clonidine, ${ }^{49}$ interferon, ${ }^{43,44}$ alphaprodine, ${ }^{118}$ amphotericin $\mathrm{B},{ }^{50}$ and intra-arterial injection of propoxyphene. ${ }^{52}$ The exact mechanisms are not well-studied.

Methemoglobinemia and sulfhemoglobinemia produced by a variety of toxic exposures may cause acrocyanosis but may be misdiagnosed as other conditions (e.g. Raynaud's phenomenon). ${ }^{3,51}$ Butyl nitrite-induced acrocyanosis has been reported. ${ }^{56}$

Secondary acrocyanosis is also associated ${ }^{101}$ with many malignant and benign ${ }^{28}$ neoplasms with or without cryoglobulins, and may be the presenting symptom. ${ }^{32,153}$ Multiple reports describe an association between acrocyanosis and cold agglutinins, cryoglubulins, or cryofibrinogen. ${ }^{28,33,154-156}$ Almost a third of all patients with positive antiphospholipid antibodies have acrocyanosis. ${ }^{30,40,157,158}$ Anti-cardiolipin antibodies have been reported in patients with acrocyanosis. In this report, the term 'essential acrocyanosis' may not be justifiable, given that a quarter of the patients developed digital necrosis. ${ }^{159}$ Many existing reports lack sufficient details, therefore some of the associations between acrocyanosis and 
neoplasms may be confounded by the presence of cold agglutinins, cryoglobulins, cryofibrinogen, and antiphospholipid antibodies.

In infections, acrocyanosis may be associated with hypoxemia, the presence of cryoglobulins, or DIC ${ }^{85}$ although the exact mechanisms may be complex. In some infections and in sarcoidosis, acrocyanosis is associated with reactive angioendotheliomatosis characterized by proliferation of cells in the reticular and papillary dermal capillaries and venules. These processes cause occlusion of the affected vessels by intravascular deposition of cryoproteins. ${ }^{160-162}$

In 'puffy hand syndrome', associated with hepatitis $\mathrm{C}$ infection in intravenous drug abusers, acrocyanosis-type changes result presumably from injuries to chronic lymphatic vessels and protein extravasation. 89,90

Abnormalities of autonomic peripheral vascular regulation of are associated with acrocyanosis. ${ }^{77}$ In patients with orthostatic intolerance, cutaneous cyanosis is caused by blunted arterial vasoconstriction combined with decreased overall blood flow in the affected extremities, but not by increased venous capacitance or 'pooling'. The distribution of the cyanosis in the dependent extremities exceeds the typical 'gloves and socks' limits seen in primary acrocyanosis. ${ }^{63,164}$ In spinal cord injury, acrocyanosis may result from venous dilation due to loss of normal vasomotor tone in the abdomen and extremities. ${ }^{80}$

In starvation and eating disorders, secondary acrocyanosis often appears early, within the first 2 months. ${ }^{100}$ Its frequency and severity are proportionate to the weight reduction and are associated with abnormal thermoregulation. ${ }^{26,27,99}$

Although vasculopathies are reported consistently in ethylmalonic encephalopathy and clinically similar cytochrome $\mathrm{C}$ oxidase deficiency, the mechanism of acrocyanosis is not known. Elevated levels of plasminogen activator inhibitor-1 may be involved. ${ }^{165}$

\section{Treatment}

There is no consensus on therapeutics and all recommendations for the treatment of acrocyanosis reflect individual practices and lack of clinical trials. Avoidance of cold exposure and trauma along with measures to improve local circulation and decrease arteriospasm are the primary focus of treatment for both primary and secondary acrocyanosis. However, cold temperature conditioning has been successful in cooperative patients. ${ }^{98} \mathrm{~A}$ trial of low molecular weight dextran to improve the rheologic properties of blood in acrocyanosis showed no effect. ${ }^{166}$ In most cases, vasoactive drugs can be avoided. Unlike Raynaud's patients, some patients with acrocyanosis were reported to improve with the use of beta-blockers, presumably due to blocking of peripheral catecholamine actions; however, this seems unlikely and we were unable to verify this singular report. ${ }^{1}$ In contrast, with Raynaud's phenomenon, calcium channel blockers have not been very helpful in acrocyanosis. Merlen reports that use of bioflavinoids may be efficacious thanks to their tonic effect on capillary-venular endothelial cells and interstitium. ${ }^{98}$ Nicotinic acid derivatives have been used in a clinical trial with some effect but with greatly variable responses. ${ }^{167,168}$ While outcomes are not reported, other recommendations include use of hexyl nicotinate $2 \%$ cream and ultraviolet light (UVB). ${ }^{169}$ Sympathetic nerve block and sympathectomy are occasionally used in severe cases. ${ }^{170-172}$

\section{Treatment of secondary forms of acrocyanosis}

In secondary acrocyanosis, treatment directed against the primary cause may lead to improvement. In anorexia nervosa, nifedipine improved chilblains and Raynaud's 
phenomenon but had no effect on acrocyanosis, while ketanserin, a selective serotonin antagonist, led to clinical improvement. ${ }^{25}$ In a placebo-controlled trial of ketanserin in primary and secondary acrocyanosis, symptomatic improvement as well as improvement of the capillaroscopic picture and rheographic tracings was observed. ${ }^{173}$

In one report of the early stages of black foot disease, intra-arterial infusion of prostaglandin $_{1}\left(\mathrm{PGE}_{1}\right)$ resulted in stable clinical improvement (although no specific comments were made on acrocyanosis). Normalization of the microcirculatory parameters, such as skin temperature, capillary perfusion, and capillary microscopy picture also occurred. The effects of $\mathrm{PGE}_{1}$ were attributed not only to the vasodilating actions but also to possible angiogenesis. ${ }^{174}$

In a report of cold agglutinin-associated acrocyanosis in a patient with Waldenstrom's macroglobulinemia, digital temperatures improved following treatment with rituximab. ${ }^{175}$ Acrocyanosis resolved in a patient with refractory type I cryoglobulinemia treated with bortezomib. ${ }^{176}$ Other immunosuppressive agents and plasmapheresis have been used. Vaccination with monocyte-derived dendritic cells has had some success in a patient with refractory essential monoclonal cryoglobulinemia and severe acrocyanosis. ${ }^{177}$

In Sneddon's syndrome, variable association with anti-cardiolipin antibodies has been reported. It is not clear if this, or another factor, is responsible for the occurrence of acrocyanosis. Patients may respond to immunosuppressive treatment in combination with anticoagulation, nifedipine and captopril. ${ }^{70,71}$

In spinal injury patients, cutaneous symptoms may be improved by neuromuscular electrostimulation. ${ }^{80}$

\section{Conclusion}

Acrocyanosis remains a poorly understood and clinically defined entity, with few objective study methods at the disposal of clinicians and researchers. There is significant overlap of the clinical signs of acrocyanosis with other common syndromes that affect digits and present with cyanotic-appearing skin changes. Differentiating primary acrocyanosis from secondary forms of acrocyanosis may be challenging. Despite seeming familiarity, confusion and misidentification are not uncommon. The prognostic significance of observed symptoms is not always clear and causes some clinicians to grow very guarded, while others, without assessing properly the clinical context, dismiss it altogether.

Although primary acrocyanosis is thought to be a benign condition, longitudinal studies are lacking and it remains to be clarified whether it is a unique phenomenon or different entities. Secondary acrocyanosis results from a number of diverse pathological mechanisms in the context of other diseases. It often has a worse prognosis compared to primary acrocyanosis. The differential of underlying causes of secondary acrocyanosis has a wide overlap with the blue toe syndrome from which it may be different only by the extent of digital involvement.

The use of databases for patient-oriented outcomes research for the treatment of primary and secondary acrocyanosis is currently impossible due to the absence of a uniform definition of the term and more precise characterization of patient demographics. Future studies may help to eliminate the diagnostic ambiguity.

\section{Acknowledgments}

The authors are thankful to Dr Roger FJ Shepherd for sharing his rich collection of images and to Ms Patricia Erwin for assistance with development and execution of literature search. 


\section{References}

1. Davis E. Clinical aspects of acrocyanosis. Adv Microcirc. 1982; 10:101-119.

2. Davis E. Oscillometry of radial artery in acrocyanosis and cold sensitivity. J Mal Vasc. 1992; 17:214-217. [PubMed: 1431608]

3. Kermani TA, Pislaru SV, Osborn TG. Acrocyanosis from phenazopyridine-induced sulfhemoglobinemia mistaken for Raynaud phenomenon. J Clin Rheumatol. 2009; 15:127-129. [PubMed: 19300288]

4. Schulze UME, Pettke-Rank CV, Kreienkamp M, et al. Dermatologic findings in anorexia and bulimia nervosa of childhood and adolescence. Pediatr Dermatol. 1999; 16:90-94. [PubMed: 10337669]

5. Tyler I, Birmingham CL. The interrater reliability of physical signs in patients with eating disorders. Int J Eat Disord. 2001; 30:343-345. [PubMed: 11767717]

6. Crocq M. De 1' “acrocyanose”. Semaine Med. 1896; 16:298.

7. Hallam R. The relationship between erythema pernio and acrocyanosis. Med Press Circ. 1930; 129:408-412.

8. Merlen JF. Capillary disturbances in man. Clin Hemorheol. 1982; 2:745-751.

9. Cannas F, Binaghi F. Nailfold capillaroscopy and laser Doppler flowmetry during standardised cold challenge to evaluate capillary pattern and digital flow in idiopathic acrocyanosis. Panminerva Med. 2002; 44:123-127. [PubMed: 12032430]

10. Allegra, C.; Carlizza, A.; Pollari, G.; Inglese, A. Acrocyanotic disease: experimental findings. In: Strano, A.; Novo, A., editors. International congress series no. 868; Advances in vascular pathology 1989: proceedings of the 15th World Congress of the International Union of Angiology; Rome. 17-22 September 1989; Amsterdam; New York: Excerpta Medica; 1989. p. 1221-1224.

11. WHO. International Classification of Diseases (ICD). Geneva: WHO; 2007.

12. Cooke JP, Marshall JM. Mechanisms of Raynaud's disease. Vasc Med. 2005; 10:293-307. [PubMed: 16444858]

13. Coffman, JD. Acrocyanosis. In: Creager, MA.; Dzau, VJ.; Loscalzo, J., editors. Vascular medicine: a companion to Braunwald's heart disease. Philadelphia, PA: Saunders Elsevier; 2006. p. 709

14. Kimura T, Yoshizaki S, Tsushima N, Sano M, Hanai G. Buerger's colour. Br J Surg. 1990; 77:1299-1301. [PubMed: 2253015]

15. Adam A, Patterson DLH. Pulmonary hypertension associated with hepatic cirrhosis and primary acrocyanosis. J R Soc Med. 1981; 74:689-691. [PubMed: 7288812]

16. Scott DD, King JC. Intermittent digital cyanosis as the sole presenting sign of pulmonary embolus: an unusual case report. Arch Phys Med Rehabil. 1994; 75:692-694. [PubMed: 8002771]

17. Arcasoy SM, Lanken PN. Pulmonary alveolar proteinosis. N Engl J Med. 2002; 347:2133. [PubMed: 12501225]

18. Metin K, Karacelik M, Yavaccan O, et al. Surgical treatment of pulmonary arteriovenous malformation: report of two cases and review of the literature. J Int Med Res. 2005; 33:467-471. [PubMed: 16104451]

19. DeWolfe CC. Apparent life-threatening event: a review. Pediatr Clin North Am. 2005; 52:11271146. [PubMed: 16009260]

20. Hendrickx I, Monti M, Manasse E, Gallotti R. Severe cutaneous cholesterol emboli syndrome after coronary angiography. Eur J Cardiothorac Surg. 1999; 15:215-217. [PubMed: 10219559]

21. Fernández MA, Andreu R, Fortea JM, Aznar J. The blue toe syndrome during oral anticoagulant therapy with acenocoumarol. Thromb Haemost. 2001; 85:743. [PubMed: 11341514]

22. Schmidt WA, Wernicke D, Kiefer E, Gromnica-Ihle E. Colour duplex sonography of finger arteries in vasculitis and in systemic sclerosis. Ann Rheum Dis. 2006; 65:265-267. [PubMed: 16410532]

23. Cholongitas E, Ioannidou D. Acrocyanosis due to cold agglutinins in a patient with rheumatoid arthritis. J Clin Rheumatol. 2009; 15:375. [PubMed: 20009982]

24. Schneiderman H. Febrile young woman with delirium and mammary ulcers. Consultant. 1997; 37:991-998. 
25. Rustin MHA, Foreman JC, Dowd PM. Anorexia nervosa associated with acromegaloid features, onset of acrocyanosis and Raynaud's phenomenon and worsening of chilblains. J R Soc Med. 1990; 83:495-496. [PubMed: 2231576]

26. Davidson CS, Wilcke HL, Reiner PJ. A nutritional survey of starvation in a group of young men. J Lab Clin Med. 1946; 31:721-734. [PubMed: 20992873]

27. Davidson CS, Wilcke HL, Fein HD, Reiner PJ. A nutrition survey of Viennese civilians under United States occupation, 1945. J Lab Clin Med. 1947; 32:1470-1481. [PubMed: 20272609]

28. Neri P, Messerotti A, Lonardo A, Capatti C, Melini L. Acrocyanosis as a heralding sign of ovarian benign teratoma. Am J Hematol. 1996; 53:53. [PubMed: 8813105]

29. Legrain S, Raguin G, Piette JC. Digital necrosis revealing ovarian cancer. Dermatology. 1999; 199:183-184. [PubMed: 10559594]

30. Kuzniar TJ, Hinchcliff M, Zunamon A, Balagani R, Enzler M, Mandzij R. Severe reversible left ventricular dysfunction associated with multiple cardiac myxomata. Wiad Lek. 2007; 60:291-293. [PubMed: 17966897]

31. Vanheste R, Vanhoenacker P, D’Haenens P. Primary cardiac lymphoma. J Belge Radiol. 2007; 90:109-111.

32. Solak Y, Aksoy S, Kilickap S, Celik I. Acrocyanosis as a presenting symptom of Hodgkin lymphoma. Am J Hematol. 2006; 81:151-152. [PubMed: 16432859]

33. Stavem P, Rorvik T, Brandtzaeg P, Brosstad F, Nordhagen R, Grabner P. Gastric lymphoma causing granulocytopenia and cold intolerance, with recovery after treatment. J Intern Med. 1991; 229:193-196. [PubMed: 1997644]

34. Pereira A, Mazzara R, Escoda L, Alcorta I, Nomdedeu B, Roelcke D. Anti-Sa cold agglutinin of IgA class requiring plasma-exchange therapy as early manifestation of multiple myeloma. Ann Hematol. 1993; 66:315-318. [PubMed: 8318562]

35. Sagripanti A, Ferretti A, Nicolini A, Carpi A. Thrombotic and hemorrhagic complications in chronic myeloproliferative disorders. Biomed Pharmacother. 1996; 50:376-382. [PubMed: 8952859]

36. Michiels JJ, Berneman Z, Schroyens W, Urk H. Aspirin-responsive painful red, blue, black toe, or finger syndrome in polycythemia vera associated with thrombocythemia. Ann Hematol. 2003; 82:153-159. [PubMed: 12634947]

37. Shimizu A, Tamura A, Ishikawa O. Livedo racemosa as a cutaneous manifestation of polycythemia vera. Eur J Dermatol. 2006; 16:312-313. [PubMed: 16709504]

38. Lauchli S, Widmer L, Lautenschlager S. Cold agglutinin disease-the importance of cutaneous signs. Dermatology. 2001; 202:356-358. [PubMed: 11455160]

39. Sinha A, Richardson G, Patel RT. Cold agglutinin related acrocyanosis and paroxysmal haemolysis. Eur J Vasc Endovasc Surg. 2005; 30:563-565. [PubMed: 16023873]

40. Diogenes MJN, Diogenes PCN, de Morais Carneiro RM, Neto CCR, Duarte FB, Holanda RRA. Cutaneous manifestations associated with antiphospholipid antibodies. Int J Dermatol. 2004; 43:632-637. [PubMed: 15357740]

41. Anderson RP, Morris BA. Acrocyanosis due to imipramine. Arch Dis Child. 1988; 63:204-205. [PubMed: 3348672]

42. Karakaya I, Aydoğan M, Coşkun A, Gökalp AS. Acrocyanosis as a side effect of tricyclic antidepressants: a case report. Turk J Pediatr. 2003; 45:155-157. [PubMed: 12921305]

43. Campo-Voegeli A, Estrach T, Marti RM, Corominas N, Tuset M, Mascaro JM. Acrocyanosis induced by interferon alpha(2a). Dermatology. 1998; 196:361-363. [PubMed: 9621152]

44. Watanabe M, Kohge N, Akagi S, Uchida Y, Sato S, Kinoshita Y. Congenital anomalies in a child born from a mother with interferon-treated chronic hepatitis B. Am J Gastroenterol. 2001; 96:1668-1669. [PubMed: 11374741]

45. Tahara H, Kojima A, Hirokawa T, et al. Systemic sclerosis after interferon alphacon-1 therapy for hepatitis C. Intern Med. 2007; 46:473-476. [PubMed: 17443037]

46. Klein M, Weksler N, Borer A, Koyfman L, Kesslin J, Gurman GM. Terlipressin facilitates transport of septic patients treated with norepinephrine. Isr Med Assoc J. 2006; 8:691-693. [PubMed: 17125115] 
47. Winkler MJ, Trunkey DD. Dopamine gangrene. Association with disseminated intravascular coagulation. Am J Surg. 1981; 142:588-591. [PubMed: 7304816]

48. Mahe E, Morelon E, Lechaton S, et al. Cutaneous adverse events in renal in renal transplant recipients receiving sirolimus-based therapy. Transplantation. 2005; 79:476-482. [PubMed: 15729175]

49. Nami R, Groppa A, Gennari C. Hypertension in the elderly. A controlled clinical trial of dihydroergotoxine mesylate and clonidine. Acta Therapeutica. 1984; 10:53-67.

50. Ozaras R, Yemisen M, Mete B, Mert A, Ozturk R, Tabak F. Acrocyanosis developed with amphotericin B deoxycholate but not with amphotericin B lipid complex. Mycoses. 2007; 50:242. [PubMed: 17472626]

51. Jiminez MA, Polena S, Coplan NL, Patel K, Gintautas J. Methemoglobinemia and transesophageal echo. Proc West Pharmacol Soc. 2007; 50:134-135. [PubMed: 18605250]

52. Pearlman HS, Wollowick BS, Alvarez EV. Intra-arterial injection of propoxyphene into brachial artery. JAMA. 1970; 214:2055-2057. [PubMed: 5536481]

53. Correia O, Ribas F, Azevedo R, Rodrigues H, Delgado L. Gangrene of the fingertips after bleomycin and methotrexate. Cutis. 2000; 66:271-272. [PubMed: 11109149]

54. The PREVENT Study Group. Reduction of respiratory syncytial virus hospitalization among premature infants and infants with bronchopulmonary dysplasia using respiratory syncytial virus immune globulin prophylaxis. Pediatrics. 1997; 99:93-99. [PubMed: 8989345]

55. Stone MJ, Sausville EA, Fay JW, et al. A phase I study of bolus versus continuous infusion of the anti-CD19 immunotoxin, IgG-HD37-dgA, in patients with B-cell lymphoma. Blood. 1996; 88:1188-1197. [PubMed: 8695836]

56. Hoegl L, Thoma-Greber E, Poppinger J, Rocken M. Butyl nitrite-induced acrocyanosis in an HIVinfected patient. Arch Dermatol. 1999; 135:90-91. [PubMed: 9923790]

57. Borgono JM, Vicent P, Venturino H, Infante A. Arsenic in the drinking water of the city of Antofagasta: epidemiological and clinical study before and after the installation of a treatment plant. Environ Health Perspect. 1977; 19:103-105. [PubMed: 908283]

58. Yang CC, Deng JF. Clinical experience in poisonings following exposure to blasticidin S, a curiously strong fungicide. Vet Hum Toxicol. 1996; 38:107-112. [PubMed: 8693684]

59. Burlina AB, Dionisi-Vici C, Bennett MJ, et al. A new syndrome with ethylmalonic aciduria and normal fatty acid oxidation in fibroblasts. J Pediatr. 1994; 124:79-86. [PubMed: 8283379]

60. Grosso S, Mostardini R, Farnetani MA, et al. Ethylmalonic encephalopathy: further clinical and neuroradiological characterization. J Neurol. 2002; 249:1446-1450. [PubMed: 12382164]

61. McGowan KA, Nyhan WL, Barshop BA, et al. The role of methionine in ethylmalonic encephalopathy with petechiae. Arch Neurol. 2004; 61:570-574. [PubMed: 15096407]

62. Garcia-Silva MT, Campos Y, Ribes A, et al. Encephalopathy, petechiae, and acrocyanosis with ethylmalonic aciduria associated with muscle cytochrome c oxidase deficiency. J Pediatr. 1994; 125:843-844. [PubMed: 7965445]

63. Garcia-Silva MT, Ribes A, Campos Y, Garavaglia B, Arenas J. Syndrome of encephalopathy, petechiae, and ethylmalonic aciduria. Pediatr Neurol. 1997; 17:165-170. [PubMed: 9367300]

64. Bodemer C, Rotig A, Rustin P, et al. Hair and skin disorders as signs of mitochondrial disease. Pediatrics. 1999; 103:428-433. [PubMed: 9925836]

65. Navarro V, Scott C, Briggs TA, et al. Two further cases of spondyloenchondrodysplasia (SPENCD) with immune dysregulation. Am J Med Genet A. 2008; 146A:2810-2815. [PubMed: 18924170]

66. Ohtake N, Sou K, Tsukamoto K, Furue M, Tamaki K. Diffuse palmoplantar keratoderma associated with acrocyanosis and livedo reticularis. Two sporadic cases. Acta Derm Venereol. 1995; 75:331. [PubMed: 8578969]

67. Fleming C, Rennie A, Fallowfield M, McHenry PM. Cutaneous manifestations of fucosidosis. Br J Dermatol. 1997; 136:594-597. [PubMed: 9155966]

68. Madan V, Williams J, Lear JT. Dermatological manifestations of Down's syndrome. Clin Exp Dermatol. 2006; 31:623-629. [PubMed: 16901300] 
69. Oiglane-Shlik E, Zordania R, Varendi H, et al. The neonatal phenotype of Prader-Willi syndrome. Am J Med Genet A. 2006; 140A:1241-1244. [PubMed: 16642508]

70. Lotz BP, Schutte CM, Colin PF, Biermann LD. Sneddon's syndrome with anticardiolipin antibodies—complications and treatment. S Afr Med J. 1993; 83:663-664. [PubMed: 8310361]

71. Fujimoto K, Shimomura T, Okumura Y, Kimura F, Takahashi Y. Intracerebral hemorrhage associated with livedo racemosa. J Stroke Cerebrovasc Dis. 2000; 9:139-143. [PubMed: 17895211]

72. Abdel-Salam GMH, Zaki MS, Lebon P, Meguid NA. Aicardi-Goutieres syndrome: clinical and neuroradiological findings of 10 new cases. Acta Paediatr. 2004; 93:929-936. [PubMed: 15303808]

73. Orcesi S, La Piana R, Fazzi E. Aicardi-Goutires syndrome. Br Med Bull. 2009; 89:183-201. [PubMed: 19129251]

74. Yatsu F, Zussman W. Familial dysautonomia (Riley-Day syndrome). Case report with postmortem findings of a patient at age 31. Arch Neurol. 1964; 10:459-463. [PubMed: 14120637]

75. Kobayasi T, Ullman S. Ehlers Danlos syndrome. Eur J Dermatol. 1995; 5:167-168.

76. Kobayasi T, Ullman S. Twisted collagen fibrils in acrocyanosis. Eur J Dermatol. 1999; 9:285-288. [PubMed: 10356406]

77. McMeekin H. Autonomic peripheral vascular dysregulation and mood disorder. J Affect Disord. 2002; 71:277-279. [PubMed: 12167529]

78. Carpenter PK, Morris D. Association of acrocyanosis with Asperger's syndrome. J Ment Defic Res. 1990; 34(Pt 1):87-90. [PubMed: 2325122]

79. Stewart JM. Chronic orthostatic intolerance and the postural tachycardia syndrome (POTS). J Pediatr. 2004; 145:725-730. [PubMed: 15580191]

80. Twist DJ. Acrocyanosis in a spinal cord injured patient- effects of computer-controlled neuromuscular electrical stimulation: a case report. Phys Ther. 1990; 70:45-49. [PubMed: 2294533]

81. Rosen Z, Davis E. Conjunctival and nailbed biomicroscopy in atrophic ozenatous rhinopathy. Pract Otorhinolaryngol (Basel). 1970; 32:356-363. [PubMed: 5510641]

82. Boettger MK, Bar KJ, Dohrmann A, et al. Increased vagal modulation in atopic dermatitis. J Dermatol Sci. 2009; 53:55-59. [PubMed: 18790607]

83. Kounis NG, Hahalis G, Theoharides TC. Coronary stents, hypersensitivity reactions, and the Kounis syndrome. J Interv Cardiol. 2007; 20:314-323. [PubMed: 17880327]

84. Aubin F, Dufour MP, Risold JC, Lucas A, Humbert P. Nailfold capillary microscopy in human immunodeficiency virus-infected patients: a case-control study. Microvasc Res. 1999; 58:197199. [PubMed: 10458938]

85. Semel JD. Cutaneous findings in a case of psittacosis. Arch Dermatol. 1984; 120:1227-1229. [PubMed: 6476861]

86. Valamparampil JJ, Chirakkarot S, Letha S, Jayakumar C, Gopinathan KM. Clinical profile of Chikungunya in infants. Ind J Pediatr. 2009; 76:151-155.

87. Dickerman JD, Howard P, Dopp S, Staley R. Infectious mononucleosis initially seen as coldinduced acrocyanosis: association with auto-anti-M and anti-I antibodies. Am J Dis Child. 1980; 134:159-160. [PubMed: 7352441]

88. Iguchi S, Toba K, Fuse I, et al. Severe cryoglobulinemia in a patient with asymptomatic hepatitis C virus infection. Intern Med. 1996; 35:712-716. [PubMed: 8915697]

89. Del Giudice P, Durant J, Dellamonica P. Hand edema and acrocyanosis: 'puffy hand syndrome'. Arch Dermatol. 2006; 142:1084-1085. [PubMed: 16924076]

90. Studdiford JS, Stonehouse AR, Anandanadesan R, Scott KC. Association between the 'puffy-hand sign' and chronic hepatitis C in a geriatric patient. J Am Geriatr Soc. 2007; 55:1694-1695.

[PubMed: 17908081]

91. Stern ES. The aetiology and pathology of acrocyanosis. Br J Dermatol. 1937; 49:100-108.

92. Mak OT. Prostacyclin production in vascular endothelium of patients with Blackfoot disease. Adv Exp Med Biol. 1988; 242:119-125. [PubMed: 3072861] 
93. Tseng WP. Effects and dose-response relationships of skin cancer and blackfoot disease with arsenic. Environ Health Perspect. 1977; 19:109-119. [PubMed: 908285]

94. Maniura-Weber K, Taylor RW, Johnson MA, et al. A novel point mutation in the mitochondrial tRNA(Trp) gene produces a neurogastrointestinal syndrome. Eur J Hum Genet. 2004; 12:509-512. [PubMed: 15054399]

95. Sivula A. Vascular reactions in acrocyanosis. Angiology. 1966; 17:269-274. [PubMed: 5936942]

96. Lottenbach K. Vascular response to cold in acrocyanosis. Helv Med Acta. 1967; 33:437-444. [PubMed: 6038437]

97. Feller SR, Dockery GL. Vasospastic diseases. Diagnosis and management. Clin Podiatr Med Surg. 1986; 3:463-471. [PubMed: 2943394]

98. Merlen JF. Paradoxes of acrocyanosis. Adv Microcirc. 1982; 10:95-100.

99. Bhanji S, Mattingly D. Acrocyanosis in anorexia nervosa. Postgrad Med J. 1991; 67:33-35. [PubMed: 2057423]

100. Hediger C, Rost B, Itin P. Cutaneous manifestations in anorexia nervosa. Schweiz Med Wochenschr. 2000; 130:565-575. [PubMed: 10842772]

101. Poszepczynska-Guigne E, Viguier M, Chosidow O, Orcel B, Emmerich J, Dubertret L. Paraneoplastic acral vascular syndrome: epidemiologic features, clinical manifestations, and disease sequelae. J Am Acad Dermatol. 2002; 47:47-52. [PubMed: 12077580]

102. Nousari HC, Kimyai-Asadi A, Anhalt GJ. Chronic idiopathic acrocyanosis. J Am Acad Dermatol. 2001; 45(6 suppl):S207-208. [PubMed: 11712060]

103. Piovella C, Fratti L, Fontana S. Modification of the terminal circulation in Raynaud's disease and acrocyanosis. Bibl Anat. 1965; 7:552-558. [PubMed: 5860790]

104. Briscoe G. Observation on venous and capillary pressures with special reference to the Raynaud Phenomena. Heart. 1918; 7:35.

105. Boas EP. The capillaries of the extremities in acrocyanosis; blood pressure and morphology. JAMA. 1922; 79:1404-1406.

106. Bollinger A, Mahler F, Meier B. Velocity patterns in nailfold capillaries of normal subjects and patients with Raynaud's disease and acrocyanosis. Bibl Anat. 1977; 16(Pt 2):142-145. [PubMed: 603500]

107. Bollinger A. Function of the precapillary vessels in peripheral vascular disease. J Cardiovasc Pharmacol. 1985; 7(suppl 3):S147-151. [PubMed: 2409388]

108. Jacobs MJ, Breslau PJ, Slaaf DW, Reneman RS, Lemmens JA. Nomenclature of Raynaud's phenomenon: a capillary microscopic and hemorheologic study. Surgery. 1987; 101:136-145. [PubMed: 3810484]

109. Hillestad LK. The peripheral circulation during exposure to cold in normals and in patients with the syndrome of high-titre cold haemagglutination. I. The vascular response to cold exposure in normal subjects. Acta Med Scand. 1959; 164:203-229. [PubMed: 14401806]

110. Lewis T, Landis EM. Observations upon the vascular mechanism in acrocyanosis. Heart. 1929; 15:229-246.

111. Elliot AH, Evans RD, Stone CS. Acrocyanosis: a study of the circulatory fault. Am Heart J. 1936; 11:431-443.

112. Skouby AP. Studies in acrocyanosis. Acta Med Scand. 1949; 134:335-345. [PubMed: 15396058]

113. Mangiafico RA, Malatino LS, Santonocito M, Spada RS, Tamburino G. Plasma endothelin-1 concentrations during cold exposure in essential acrocyanosis. Angiology. 1996; 47:1033-1038. [PubMed: 8921751]

114. Sagher F, Davis E, Sheskin J, Landau J. The small blood vessels of the skin in acrocyanosis. Comparison of biomicroscopy and biopsy findings. Br J Dermatol. 1966; 78:586-589. [PubMed: 5921985]

115. Stern S, Davis E, Landau J. Impaired 'arterialization' of the venous blood of the hand in Raynaud's disease and acrocyanosis. Angiology. 1961; 12:385-387.

116. Copeman PW. Acrocyanosis: a blood disease? Proc R Soc Med. 1973; 66:741-742. [PubMed: 4733957] 
117. Cimminiello C, Arpaia G, Milani M, et al. Platelet function in patients with acrocyanosis. Vasa. 1987; 16:12-15. [PubMed: 3577358]

118. Fuller HD. Cyanosis of the hands following the use of alphaprodine in dental anaesthesia. Can Anaesth Soc J. 1986; 33:213-215. [PubMed: 3697816]

119. Ertem K. Prolonged transient hand ischaemia secondary to a penicillin skin test. J Hand Surg Eur Vol. 2007; 32:723-725. [PubMed: 17993448]

120. Tseng C-H. An overview on peripheral vascular disease in blackfoot disease-hyperendemic villages in Taiwan. Angiology. 2002; 53:529-537. [PubMed: 12365859]

121. Shen MC, Tseng WP, Chen CS. Increased circulating platelet aggregates and coagulation factors in patients with Blackfoot disease. Taiwan Yi Xue Hui Za Zhi. 1983; 82:816-821. [PubMed: 6579233]

122. Frankel DH, Larson RA, Lorincz AL. Acral lividosis - A sign of myeloproliferative diseases. Hyperleukocytosis syndrome in chronic myelogenous leukemia. Arch Dermatol. 1987; 123:921924. [PubMed: 3475043]

123. Sharma BD, Kabra SR, Gupta B. Symmetrical peripheral gangrene. Trop Doct. 2004; 34:2-4. [PubMed: 14959959]

124. Wakeling A, Russell GF. Disturbances in the regulation of body temperature in anorexia nervosa. Psychol Med. 1970; 1:30-39. [PubMed: 5526111]

125. Clement DL. Effect of indoramin on finger blood flow in vasospastic patients. Eur J Clin Pharmacol. 1978; 14:331-333. [PubMed: 729626]

126. Noyer CM. Sertraline, a selective serotonin reuptake inhibitor, unmasking carcinoid syndrome. Am J Gastroenterol. 1997; 92:1387-1388. [PubMed: 9260818]

127. Zufferey P, Depairon M, Chamot AM, Monti M. Prognostic significance of nailfold capillary microscopy in patients with Raynaud's phenomenon and scleroderma-pattern abnormalities. A six-year follow-up study. Clin Rheumatol. 1992; 11:536-541. [PubMed: 1486747]

128. Davis MDP, Wilkins F, Rooke TW. Between episodes of erythromelalgia: A spectrum of colors. Arch Dermatol. 2006; 142:1085-1086. [PubMed: 16924077]

129. Benchikhi H, Roujeau JC, Levent M, Gouault-Heilmann M, Revuz J, Cosnes A. Chilblains and Raynaud phenomenon are usually not a sign of hereditary protein $\mathrm{C}$ and $\mathrm{S}$ deficiencies. Acta Derm Venereol. 1998; 78:351-352. [PubMed: 9779252]

130. Klein-Weigel P, Rein P, Kronenberg F, et al. Microcirculatory assessment of vascular acrosyndrome in anorexia nervosa and analysis of manifestation factors. J Psychosom Res. 2004; 56:145-148. [PubMed: 14987977]

131. Strumia R, Varotti E, Manzato E, Gualandi M. Skin signs in anorexia nervosa. Dermatology. 2001; 203:314-317. [PubMed: 11752819]

132. Peacock JH. A comparative study of the digital cutaneous temperatures and hand blood flows in the normal hand, primary Raynaud's disease and primary acrocyanosis. Clin Sci. 1959; 18:2533. [PubMed: 13639341]

133. Davis, E.; Landau, J. Clinical capillary microscopy. Springfield, IL: CC Thomas; 1966.

134. Blockmans D, Beyens G, Verhaeghe R. Predictive value of nailfold capillaroscopy in the diagnosis of connective tissue diseases. Clin Rheumatol. 1996; 15:148-153. [PubMed: 8777848]

135. Ingegnoli F, Gualtierotti R, Lubatti C, et al. Feasibility of different capillaroscopic measures for identifying nailfold microvascular alterations. Semin Arthritis Rheum. 2009; 38:289-295. [PubMed: 18166220]

136. Monticone G, Colonna L, Palermi G, Bono R, Puddu P. Quantitative nailfold capillary microscopy findings in patients with acrocyanosis compared with patients having systemic sclerosis and control subjects. J Am Acad Dermatol. 2000; 42:787-790. [PubMed: 10775855]

137. Dobrev HP. Capi text V. 1-- data analysis software for nail-fold skin capillaroscopy. Folia Med (Plovdiv). 2007; 49:84-87. [PubMed: 18504941]

138. Vayssairat M, Abuaf N, Deschamps A, et al. Nailfold capillary microscopy in patients with anticardiolipin antibodies: a case-control study. Dermatology. 1997; 194:36-40. [PubMed: 9031789] 
139. Maricq HR. Comparison of quantitative and semiquantitative estimates of nailfold capillary abnormalities in scleroderma spectrum disorders. Microvasc Res. 1986; 32:271-276. [PubMed: 3762432]

140. Arpaia G, Cimminiello C, Milani M, et al. A new capillaroscopic assessment of microvascular damage vs Maricq classification in patients with isolated Raynaud phenomenon. Int Angiol. 1989; 8:129-133. [PubMed: 2592795]

141. Lefford F, Edwards JC. Nailfold capillary microscopy in connective tissue disease: a quantitative morphological analysis. Ann Rheum Dis. 1986; 45:741-749. [PubMed: 3490228]

142. Poole CJ. Cold haemagglutinin disease misdiagnosed as hand-arm vibration syndrome. Occup Med (Lond). 2008; 58:219-221. [PubMed: 18359951]

143. Yucel AE, Kart-Koseoglu H, Demirhan B, Ozdemir FN. Cholesterol crystal embolization mimicking vasculitis: success with corticosteroid and cyclophosphamide therapy in two cases. Rheumatol Int. 2006; 26:454-460. [PubMed: 16025335]

144. Karmody AM, Powers SR, Monaco VJ, Leather RP. 'Blue toe' syndrome. An indication for limb salvage surgery. Arch Surg. 1976; 111:1263-1268. [PubMed: 985075]

145. Feder W, Auerbach R. 'Purple toes': an uncommon sequela of oral coumarin drug therapy. Ann Intern Med. 1961; 55:911-917. [PubMed: 13891942]

146. Otsubo H, Kaito K, Takahashi H, et al. Cholesterol emboli following percutaneous transluminal coronary angioplasty as speculated by toe skin biopsy. Intern Med. 1995; 34:134-137. [PubMed: 7727880]

147. Tamura K, Umemura M, Yano H, et al. Acute renal failure due to cholesterol crystal embolism treated with LDL apheresis followed by corticosteroid and candesartan. Clin Exp Nephrol. 2003; 7:67-71. [PubMed: 14586747]

148. Hirschmann JV, Raugi GJ. Blue (or purple) toe syndrome. J Am Acad Dermatol. 2009; 60:1-20. [PubMed: 19103358]

149. Brown PJ, Zirwas MJ, English JC. The purple digit: an algorithmic approach to diagnosis. Am J Clin Dermatol. 2010; 11:103-116. [PubMed: 20141231]

150. McAllister SF, Cleary JD. Blue digits: cyanosis resulting from norepinephrine treatment. Ann Pharmacother. 2005; 39:383-384. [PubMed: 15644482]

151. Lutwak L. An acute terminal episode with fever, nausea, vomiting, diarrhea and acrocyanosis in a patient with rheumatoid arthritis. Am J Med. 1964; 37:294-304. [PubMed: 14206760]

152. Lin YC, Liang TH, Chang HN, Lin JS, Lin HY. Behcet disease associated with myelodysplastic syndrome. J Clin Rheumatol. 2008; 14:169-174. [PubMed: 18525438]

153. Smith P, Rice M, Ricci N, Toogood I, Roberton D. A case of Burkitt's lymphoma presenting with digital ischaemia. Acta Paediatr. 1993; 82:217-219. [PubMed: 8477174]

154. Chuang SS, Lin CC. Cold agglutininemia with acrocyanosis in multicentric Castleman's disease: a case report. Changgeng Yi Xue Za Zhi. 1995; 18:378-382. [PubMed: 8851989]

155. Wulffraat N, Meyer KJT, Zegers BJM, Kuis W. Familial presence of primary cryofibrinogenaemia, a report of three cases. Br J Rheumatol. 1996; 35:102-104. [PubMed: 8624616]

156. Young S, Haldane G. Major colorectal surgery in a patient with cold agglutinin disease. Anaesthesia. 2006; 61:593-596. [PubMed: 16704598]

157. Salluh JIF, Soares M, Meis ED. Antiphospholipid antibodies and multiple organ failure in critically ill cancer patients. Clinics. 2009; 64:79-82. [PubMed: 19219311]

158. Naldi L, Locati F, Marchesi L, et al. Cutaneous manifestations associated with antiphospholipid antibodies in patients with suspected primary antiphospholipid syndrome: a case-control study. Ann Rheum Dis. 1993; 52:219-222. [PubMed: 8484676]

159. Vayssairat M, Abuaf N, Baudot N, Deschamps A, Gaitz JP. Abnormal IgG cardiolipin antibody titers in patients with Raynaud's phenomenon and/or related disorders: prevalence and clinical significance. J Am Acad Dermatol. 1998; 38:555-558. [PubMed: 9555793]

160. Shyong EQ, Gorevic P, Lebwohl M, Phelps RG. Reactive angioendotheliomatosis and sarcoidosis. Int J Dermatol. 2002; 41:894-897. [PubMed: 12530356]

161. Martens HA, Bijl M. Blue-purple ears. Arthritis Rheum. 2007; 56:673. [PubMed: 17265503] 
162. Porras-Luque JI, Fernandez-Herrera J, Dauden E, Fraga J, Fernandez-Villalta MJ, Garcia-Diez A. Cutaneous necrosis by cold agglutinins associated with glomeruloid reactive angioendotheliomatosis. Br J Dermatol. 1998; 139:1068-1072. [PubMed: 9990375]

163. Stewart JM. Pooling in chronic orthostatic intolerance: arterial vasoconstrictive but not venous compliance defects. Circulation. 2002; 105:2274-2281. [PubMed: 12010910]

164. Stewart JM, Weldon A. The relation between lower limb pooling and blood flow during orthostasis in the postural orthostatic tachycardia syndrome of adolescents. J Pediatr. 2001; 138:512-519. [PubMed: 11295714]

165. McGowan KA, Barshop BA, Naviaux RK, Haas RH, Yu A, Nyhan WL. Ethylmalonic encephalomyopathy with petechiae: reduction in ethylmalonic acid excretion with methionine restriction and delineation of coagulopathy. Invest Ophthalmol Vis Sci. 1996; 37:24A.

166. Zackheim HS, Farber EM, Aschheim E. Effect of low molecular weight dextran on acrocyanosis and scleroderma. Dermatologica. 1969; 139:145-153. [PubMed: 5810899]

167. Kamimura M. Comparative studies of the effects of alpha-tocopheryl nicotinate and the combination alpha-tocopheryl acetate and nicotinic acid. Nutr Sci Vitaminol (Tokyo). 1973; 19:375-381.

168. Holti G. Experimentally controlled evaluation of vasoactive drugs in digital ischemia. Angiology. 1978; 29:89-94. [PubMed: 343655]

169. Jordaan HF. The diagnosis and management of perniosis (chilblains). South African Family Practice. 2007; 49:28-29.

170. Rickles JA. Ambulatory use of sympathetic nerve blocks: present day clinical indications. Angiology. 1977; 28:394-402. [PubMed: 68691]

171. Di Lorenzo N, Sica GS, Sileri P, Gaspari AL. Thoracoscopic sympathectomy for vasospastic diseases. J Soc Laparoendosc Surg. 1998; 2:249-253.

172. Moini M, Rasouli MR. Thoracoscopic servicothoracic sympathectomy for treatment of upper extremity ischemia. World J Surg. 2008; 32:331-332. [PubMed: 18027018]

173. Allegra C, Tonelli V. Results of a double-blind placebo controlled study with a serotonine selective antagonist (ketanserin) in the treatment of 30 patients with acrocyanotic syndrome. Clinica e Terapia Cardiovascolare. 1985; 4:39-45.

174. Chang CH, Yu HS, Chen GS, Wang MT, Ko SS. Study on blackfoot disease: with special reference to evaluating its cutaneous microcirculatory status. Gaoxiong Yi Xue Ke Xue Za Zhi. 1993; 9:559-566. [PubMed: 8133542]

175. Hattori N, Ishii N, Ariizumi H, et al. Improvement of the thermal amplitude after rituximab treatment for cold agglutinin disease with Waldenstrom's macroglobulinemia. Ann Hematol. 2010; 89:103-104.

176. Talamo G, Claxton D, Tricot G, Fink L, Zangari M. Response to bortezomib in refractory type I cryoglobulinemia. Am J Hematol. 2008; 83:883-884. [PubMed: 18756542]

177. Maeda M, Inaba S, Nomura A, et al. Vaccination of a refractory essential monoclonal cryoglobulinemia patient with cryoglobulin-pulsed dendritic cells. Leuk Lymphoma. 2000; 39:441-446. [PubMed: 11342327] 


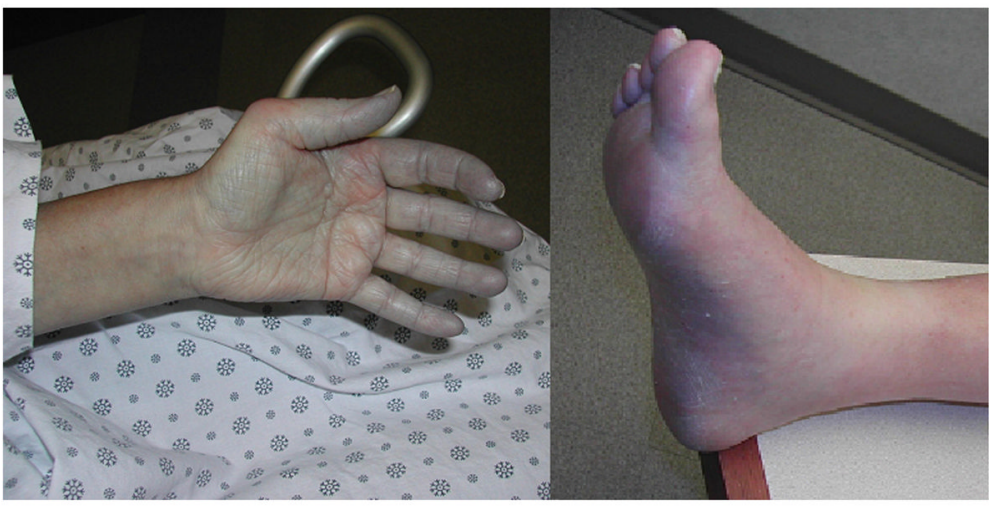

Figure 1.

Hand and foot of a patient with acrocyanosis. 


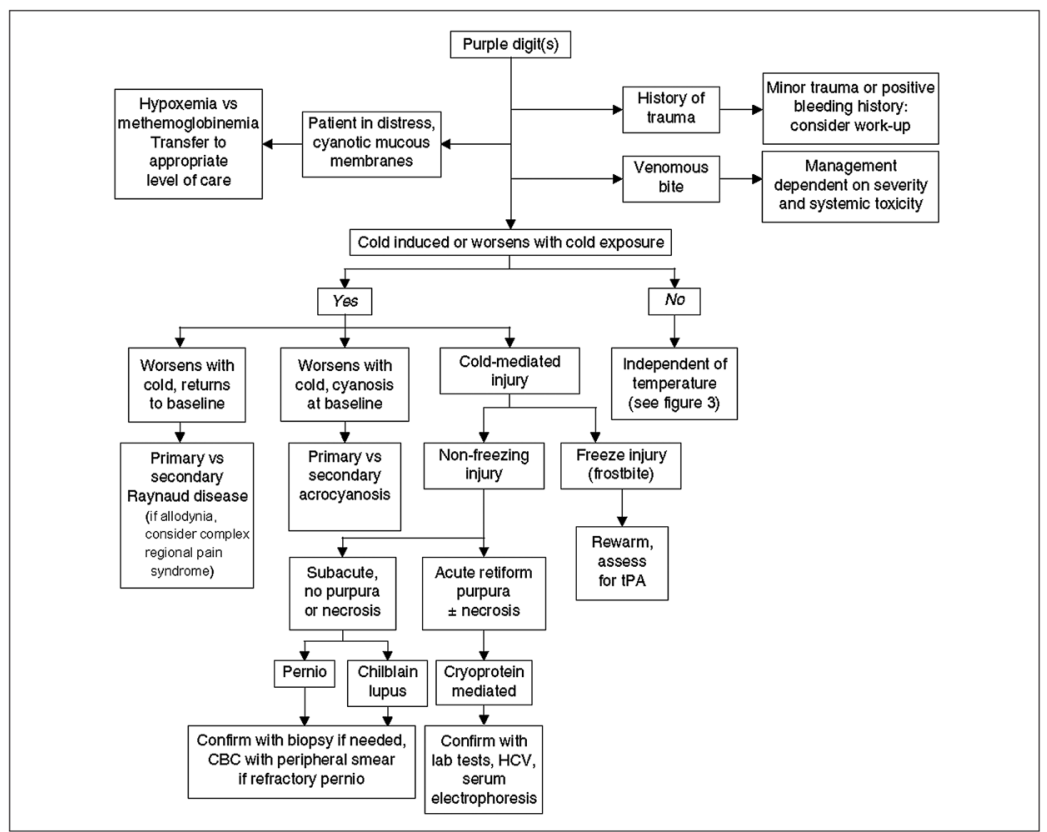

Figure 2.

Approach to the diagnosis of purple digits in an adult. (CBC, complete blood count; HCV, hepatitis $\mathrm{C}$ virus; tPA, alteplase [tissue plasminogen activator].) Reproduced from ref. 149 with permission from Adis, a Wolters Kluwer business (@) Adis Data Information BV 2010. All rights reserved). 


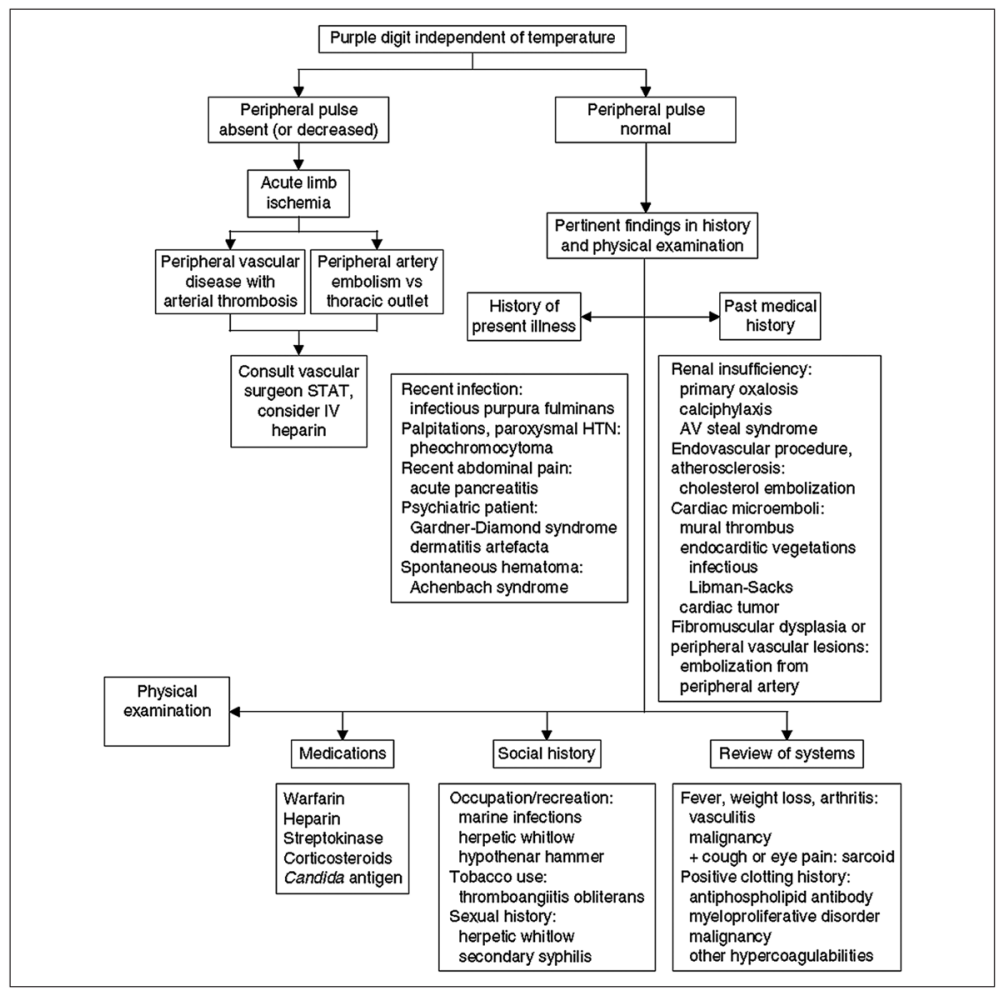

Figure 3.

Approach to the diagnosis of purple digits in an adult independent of temperature. (AV, arteriovenous; HTN, hypertension; STAT, immediately.) Reproduced from ref. 149 with permission from Adis, a Wolters Kluwer business (C) Adis Data Information BV 2010. All rights reserved). 
Table 1

Causes of secondary acrocyanosis (modified from Coffman ${ }^{13}$ )

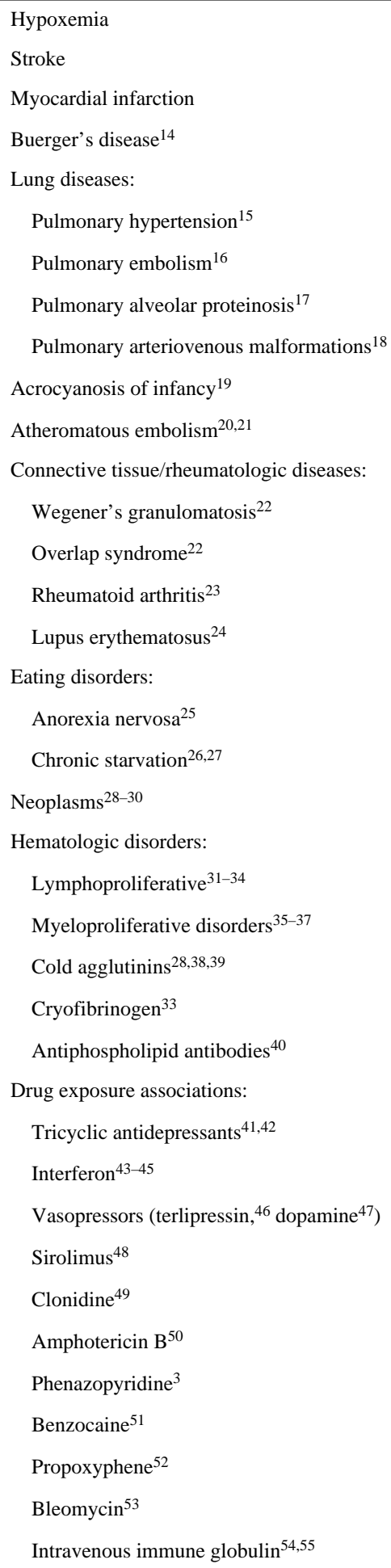


Butyl nitrite 56

Toxicities:

Arsenic $^{57}$

Blasticidin $\mathrm{S}^{58}$

Heritable diseases:

Ethylmalonic aciduria ${ }^{59-61}$

Cytochrome C oxidase deficiency ${ }^{62,63}$

Mitochondrial disease (oxidative phosphorylation disorders) ${ }^{64}$

Spondyloenchondrodysplasia ${ }^{65}$

Palmoplantar keratoderma syndrome ${ }^{66}$

Fucosidosis $^{67}$

Down's syndrome ${ }^{68}$

Prader-Willi syndrome ${ }^{69}$

Sneddon's syndrome $\mathrm{e}^{70,71}$

Aicardi-Goutières syndrome ${ }^{72,73}$

Marfan's disease

Riley-Day syndrome (familial dysautonomia) ${ }^{74}$

Ehlers-Danlos syndrome ${ }^{75,76}$

Psychiatric:

Bipolar disorder ${ }^{77}$

Asperger's syndrome ${ }^{78}$

Orthostatic intolerance and postural tachycardia syndrome (POTS) $)^{79}$

Spinal cord injury ${ }^{80}$

Ozena $^{81}$

Chronic hypertrophic and primary atrophic rhinitis ${ }^{81}$

Atopic dermatitis $^{82}$

Hypersensitivity coronary syndrome (Kounis syndrome) ${ }^{83}$

Infections:

HIV $^{84}$

Psittacosis ${ }^{85}$

Chikungunya infection ${ }^{86}$

Mononucleosis $^{87}$

Hepatitis $\mathrm{C}^{88}$

'Puffy hand syndrome' 89,90 